\title{
VISCOSITY AND VORTEX FORMATION IN A LIQUID PLACED IN A ROTATING CYLINDRICAL VESSEL
}

\author{
(D) Oksana L. Andrieievaa,b,*, (D) Leonid A. Bulavin', (D) Igor N. Kudriavtsev ${ }^{\mathrm{b}}$, \\ (D) Roman S. Sokolenko ${ }^{a}$, DVictor I. Tkachenko ${ }^{\mathrm{a}, \mathrm{b}}$ \\ ${ }^{a}$ National Science Center "Kharkiv Institute of Physics and Technology", Kharkiv \\ ${ }^{b}$ V. N. Karazin Kharkiv National University, Kharkiv \\ ${ }^{c}$ Taras Shevchenko National University of Kyiv, Kyiv \\ *Corresponding Author: andreevaoksana@kipt.kharkov.ua, Phone +380-097-292-06-15 \\ Received July 23, 2020; revised October 28, 2020; accepted November 5, 2020
}

\begin{abstract}
The free fall of steel balls of different diameters in viscous liquids placed in a cylindrical vessel at rest or rotating at a constant rate as well as the vortex generation in a liquid rotating in a cylindrical vessel were experimentally studied. To solve the problem a test stand including a cylindrical glass vessel mounted on the axis of a governed-speed electric engine shaft, monitoring and measuring devices as part of a digital laser tachometer, a digital USB microscope and a laptop was developed to visualize the processes under study. Experimental dependences of the instantaneous velocity of the balls on the distance traveled by them were obtained. It has been demonstrated, that there is a transition mode of the ball velocity variation when it enters the liquid. The transition mode was characterized by a damped, periodic variation of instantaneous velocity depending on a distance. It has been found that at a certain distance traveled by the ball, the transition mode becomes stationary when the ball moves at a constant velocity. The dependence of the liquid viscosity on the vessel rotation frequency was studied in the stationary mode using the Stokes method. It has been demonstrated that the common behavior of such processes is decreasing the time of balls falling and, consequently, the coefficient of a liquid dynamic viscosity with increasing the rotation frequency of the vessel. A periodic variation in the coefficient of the dynamic viscosity depending on the frequency of the vessel rotation was found experimentally. It has been found experimentally that several threadlike spiral flows of a colored liquid are formed parallel to the axis of the cylinder, when the cylindrical vessel rotates. At that, the velocity of the downward drift of the colored liquid increases with increasing its rotation rate and it increases from the periphery to the center of the vessel.
\end{abstract}

KEYWORDS: liquid, cylindrical vessel, steady speed, viscosity, Stokes method, rotation, dynamic viscosity, vortex

One of the methods to determine the coefficient of a liquid dynamic viscosity is the Stokes method (SM). This method is based on application of the formula for the resistance force of a straight-line and uniform motion-of a ball in a viscous liquid, first obtained by Stokes [1]. Its essence consists in setting up an equation of balance of forces acting in a viscous liquid on a ball (gravity, Archimedes 'force and Stokes' force), from which the velocity of the ball stationary motion follows. In such reasoning, the effect of liquid vessel walls is not taken into account, since the diameter of the vessel exceeds significantly the diameter of the ball in the experiments. For SM applicability it is necessary to measure the viscosity in the area of uniform motion of the ball.

If the diameter of the ball is comparable to the diameter of the vessel, then the Stokes formula is not applicable and in order to determine the conditions for their stationary motion occurrence additional studies of the motion of balls in viscous liquid should be carried out. When a ball falls into a viscous liquid, two stages can be distinguished: the stage of the ball falling on the surface of the liquid and the stage of its uniform motion.

A large number of works are devoted to the study of the first stage (the ball fall on the liquid surface), among which one can name [2-5].

Fundamental experimental and theoretical calculations on the effect of solids on the water surface, which are of interest in ballistics for passing projectiles from air to water and in aeronautics - for landing seaplanes were carried out in [2]. The critical velocity of the impact of spheres on the water surface for formation of splashes, as well as the cone angle formed behind the impact object were experimentally investigated in [3].

Based on the theory of $\mathrm{H}$. Wagner [6] in [4] the problem of fast immersion in water of a body of revolution with a vertical axis of symmetry is considered and the solution of the basic integral equation is obtained. As an example, a ball entry into water was studied, the resistance force of water acting on the ball was calculated and a comparison with the experimental data was made. The proposed description is applicable for small immersion depths not exceeding 0.035 ball diameter.

The effect of a solid object on a liquid surface is analyzed in [5]. Here, a numerical algorithm is proposed for modeling the entry of the solid object into the liquid medium taking into account the dynamics of the free surface of the liquid / gas interface. In this model taking into account, high viscosity of solid objects increases the accuracy of the results of the previous studies. The conclusions of the model are confirmed by comparing the experimental data of other researchers for the free fall of a circular disk and a sphere. The model is applicable for shallow immersion depths of objects in liquid.

The processes considered in [2-5] are transient and are not characterized by determination of a stationary motion velocity. Therefore, they cannot be used to determine the media viscosity by SM. As noted above, determination of stationary velocities of spheres motion in viscous liquid vessels is of interest for viscometry purposes based on SM. 
The work [7] is devoted to this issue. It presents experimental data on the drug of cylindrical vessel walls to a sphere falling axially under the action of gravity in a viscous fluid. The data were obtained for 60 spheres of different diameters and densities, which moved in four cylinders of different diameters, and were filled with fifteen Newtonian fluids of different viscosities and densities. From the analysis of the results of more than 3000 measurements of spheres velocities it has been concluded that the wall effect is determined by two variables: the ratio of the sphere diameter to the diameter of the cylindrical vessel ( $\mathrm{d} / \mathrm{D})$ and the Reynolds number $\mathrm{R}\left(0.05<\mathrm{R}<2 \times 10^{4}\right)$ for the sphere. To describe the wall effect the authors of [7] determined the correction factors graphically in the form of the dependence of the ratio of the stationary velocity in the cylinder to the stationary velocity in an infinite mass of fluid ( $\mathrm{V} / \mathrm{V}_{\infty}$ ) on the Reynolds number at $\mathrm{V}_{\infty}$ for various ratios of diameters. It follows from the graph that the wall effect is maximal at low Reynolds numbers and large diameter ratios. For small diameter ratios (less than 0.1 ) the effect degree becomes insignificant at Reynolds numbers above 100.

In the later work on this issue [8] it is emphasized that experimental data on the motion of spheres were obtained in the twentieth century and are available in tabular form (see Historical Data [8]). Most of these data were obtained in experiments with small diameter cylindrical vessels, where the effect of a wall occurrence affects the results. The previously obtained analytical expressions for describing the dependence of the drag on the velocity of falling spheres were compared with this data set. Because of this comparison, two new descriptions of the stationary velocity of a sphere were proposed. One description is applicable for Reynolds numbers less than $2 \times 10^{5}$. The other is intended to predict the velocity of sphere falling with superior accuracy for Reynolds numbers less than 4000. This range of Reynolds numbers contains almost all applications of interest in environmental engineering.

When discussing issues related to determination of a stationary velocity of spheres motion, both in narrow and wide in diameter cylindrical vessels filled with a viscous liquid, one should be guided by the data of works [7,8].

The case, when a vessel with a viscous liquid rotates at a constant speed and a sphere moves in it, has not been analyzed in the scientific literature as to the analysis of stationary velocity determination. The issue of such studies is of scientific and practical interest for environmental engineering, medicine, shipbuilding, and aircraft engineering.

Therefore, this article presents the results of an experimental study of the viscosity of a liquid placed in a rotating cylindrical vessel. In addition to the problem of determining the viscosity of a fluid rotating in a cylindrical vessel, the problem of vortex formation in it is also of interest.

The physics of rotating liquids has been studied beginning with the Rayleigh work [9]. Rayleigh's interest in this topic was caused by the need to describe the meteorological situation, which is very dependent on the dynamics of rotating volumes of liquid (cyclones and anticyclones). So, a need to have an accurate weather forecast for a fairly long term, based on the analysis of the dynamics of liquid rotating volumes, arose. In this work Rayleigh described the main features of liquid rotating volumes typical of cyclones and anticyclones. He formulated the law of conservation of the azimuthal moment of a rotating liquid. Besides, he deduced the stability criterion for an ideal liquid located between two rotating concentrically arranged cylinders.

The following rigorous studies of the stability of a rotating liquid heated from below are given in [10]. In particular, a number of experimental results on the study of the vortex formation in rotating and bottom-heated water and air [11] are presented here.

In the experiments the water was located in Pyrex glass cylinders with an outer diameter of 12 inches. Pyrex temperature-controlled electrically conductive heating plates were glued to the cylinder bottoms. Cylinders containing the water and the necessary accessories were placed on a support steel ring mounted on a vertical shaft. The steel ring was intended for alignment and other adjustments. The cylinder was driven using the shaft rotated by means of feed belts and an engine. Water layers of a depth of 2-17 cm and a rotation speed of up to $50 \mathrm{rpm}$ were used in the experiments.

The temperature difference at two levels (one - near the upper and the other - near the lower surface of the liquid) was measured by copper - constantan wire thermocouples. The accuracy of the temperature measurement was $\pm 0.01^{\circ} \mathrm{C}$ and was sufficient to process the obtained results.

The experimental studies were of two types: visual and photographic performed using a rotoscope.

The experiments showed, that the liquid vortex motion in a rotating cylinder was observed when the rate of its bottom heating exceeded a certain value. The vortexes were visually observed in water, when a small amount of aluminum powder was dispersed above its surface. The motion of aluminum powder particles on the water surface was photographed using the time-lapse strip method and corresponded to a set of vortexes of approximately equal diameter (Fig. 1).

It follows from Fig. 1 that the traces of vortexes on the water surface are located generally near a concentric circle of a radius of about $2 / 3$ of the cylinder radius.

The internal motion in the form of ascending vortexes is presented in Fig. 2. Such vortexes are detected when using a black ink placed initially in a thin layer at the vessel bottom. Apparently, the vorticity (see the definition below) of liquid individual volumes contributes towards accelerating the diffusion of ink and, as a consequence, its diffusion rises to the upper boundary of the liquid.

Based on the comparison of theoretical studies and experimental results it was concluded that they have quantitative and qualitative conformances. Hence, the authors concluded that the formation of vortexes in a cylinder 
containing the water rotated and heated from below, when the boundaries are free above and solid below (as a whole mixed boundary conditions), has a convective nature. They have determined that in a state of instability (vortex formation) the critical Rayleigh number is proportional to the Taylor number.

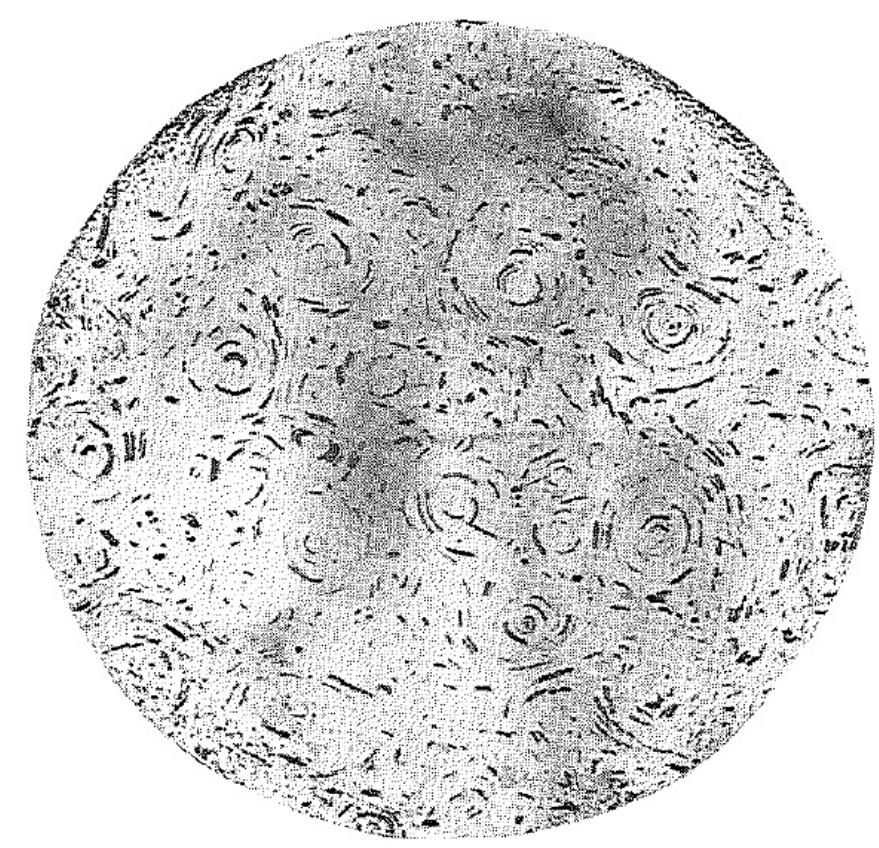

Figure 1. Convection cells which appear in water when in rotation and heated from below. The data to which the illustration refers are: depth $18 \mathrm{~cm}$; difference in temperature $0.7^{\circ}$; rate of rotation $5.0 \mathrm{rev} / \mathrm{min}$; Taylor number $-1.2 \times 10^{9}[10]$.

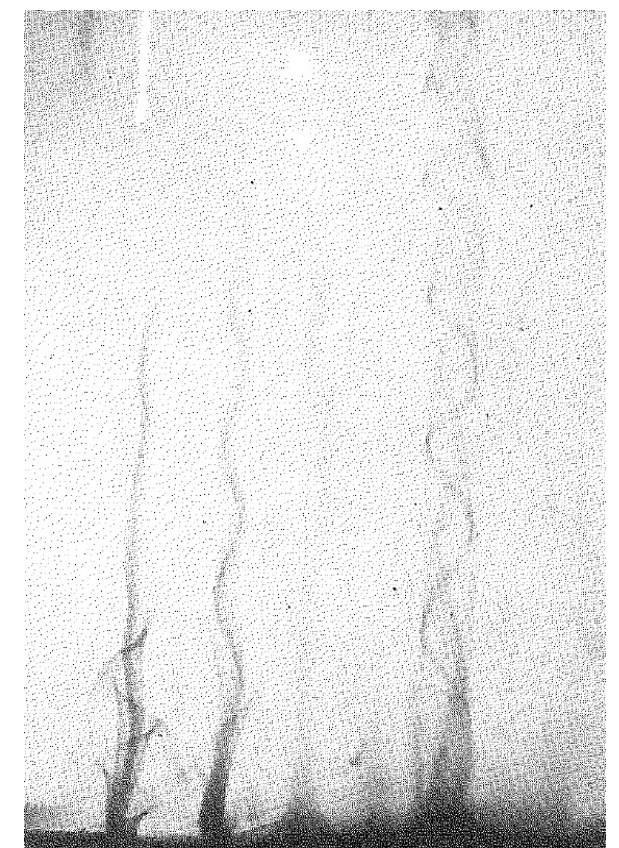

Figure 2. Side view of ink rising from the bottom of a cylinder of water in the ascending cores of cells. The data to which the illustration refers are: depth $18 \mathrm{~cm}$; difference in temperature $0.5^{\circ}$; rate of rotation $10.9 \mathrm{rev} / \mathrm{min}$; Taylor number - $5.5 \times 10^{9}[10]$.

The monograph of the famous English hydrodynamics H. Greenspan is devoted to issues of the theory of stability of a rotating liquid [12]. Such studies are used in the study of atmospheric and ocean currents on a rotating planet for weather forecasting. The author confirms the theoretical results by simple laboratory experiments using a flask rotated by a gramophone disc. The book presents the latest achievements at the time of its publication in the theory of nonstationary and non-linear motions, various oscillating (wave) processes and hydrodynamic stability.

Despite the wide topic area, the cases of vortex formation in a rotating cylinder filled with a liquid are not analyzed in [12], as described in [10].

However, it should be noted that the observed vortexes in $[10,11]$ do not have the structure of Benard convective cells [13], since the descending flows of ink-colored water are not found in the experiments. Besides, for the problem with mixed boundary conditions the local aspect number $A_{l}$ (the ratio of the cell diameter to the depth of the water layer) is in the wide range $1.25<A_{l}<10.59$, which does not correspond to the value $A_{l}=2.86$ obtained in [6 14].

These discrepancies indicate the possibility of another scenario for the formation of vortexes in a liquid located in a rotating cylinder.

It may be as follows.

A large number of ascending convective flows (termics) are generated in a rotating cylinder filled with water due to heating of the vessel bottom. The conditions for the formation of termics and their characteristic parameters are described in sufficient detail in [15]. The vortex generation place is determined by the spatial coincidence of one of the termics and the perturbation of the vertical interface of the azimuthal velocity along the cylinder radius. Such perturbations, due to the development of Kelvin - Helmholtz instability, form vortexes, which at the nonlinear stage form "cat eyes" represented in the album of liquid and gas flows [16].

Further, such vortexes leave their generation place like cyclonic and anticyclonic vortexes (rings) leave the Gulf Stream arrow as a result of meandering [17], and new ones appear at their place. At that, the rings located on opposite sides of the vertical interface of the azimuthal velocity have a different sign of vorticity $\vec{\omega}_{ \pm}[18]$ :

$$
\vec{\omega}_{ \pm}=\operatorname{rot}\left(\vec{V}_{ \pm}\right)
$$

where, $\vec{V}_{ \pm}(\vec{r})= \pm \frac{1}{2} \vec{\Omega} \times \vec{r}-$ mutually opposite rates of a simple liquid flow, $\vec{\Omega}$ - constant vector that determines the frequency of rotation of a fluid volume $\vec{\Omega}, \vec{r}$ - radius vector orthogonal to the axis of rotation. 
The experimental data (images of the upper boundaries and the axial section) on the formation of vortexes in liquid media located in rotating vessels are presented in $[10,11]$. It can be seen a large number of vortexes of almost the same size at the images. However, the temporal dynamics of the number of the appeared vortexes, their structure and rotation direction are not analyzed in these experimental data. Such an analysis would allow us to determine the physical nature of vortex generation, their internal structure and to describe the dynamics of their distribution in a liquid volume.

So, the objective of this work is experimental research of: free-falling velocity of steel balls in a cylindrical vessel containing a viscous liquid; viscosity of a liquid rotated at a constant rate in a cylindrical vessel; formation of vortexes in a liquid rotated in a cylindrical vessel at a constant rate.

\section{EXPERIMENTAL FACILITIES}

For research the test stand was developed and assembled (see Fig. 1,2) [19]. This test stand includes: a cylindrical glass vessel (1) of a diameter of $28 \mathrm{~mm}$ mounted on the axis of the electric motor shaft the revolutions of which are continuously controlled using the appropriate driver. The stand has also monitoring and measuring devices: a digital laser tachometer HS2234 with an accuracy of rotation frequency measuring equal to $0.1 \mathrm{rpm}$ (2); USB digital microscope (3) connected to a laptop to visualize the motion of balls and liquid that were recorded on video.

An electronic precision jewelry balance with an accuracy of $0.01 \mathrm{~g}$ and a power supply unit of a voltage of $12 \mathrm{~V}$ were used to ensure the stand operation.

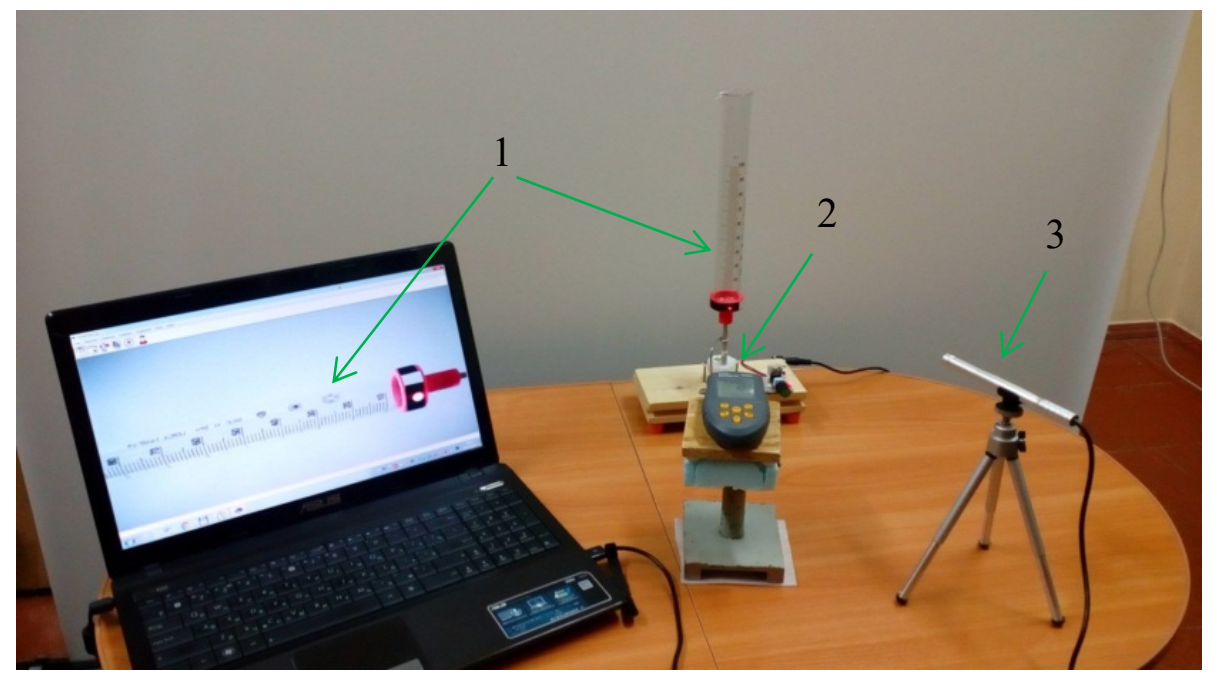

Figure 3. Measuring stand with the visualization system

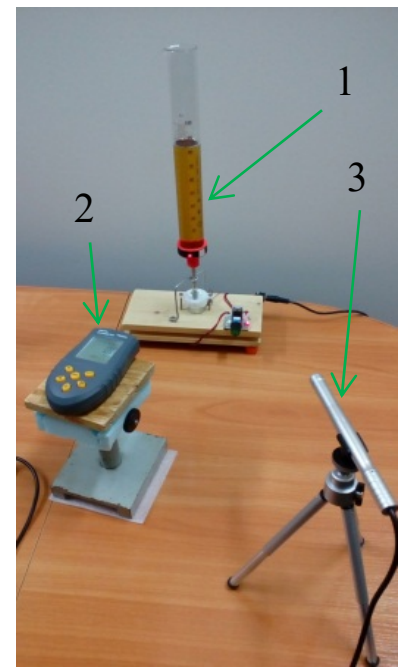

Figure 4. Fragment of the measuring bench

Engine oil of grade 10W40 and an aqueous solution of glycerol with glycerol concentration of $85 \%$ were used as a viscous liquid. Steel balls about 3 and $6 \mathrm{~mm}$ in diameter were used for viscosity measurement.

An experimental study of a free fall of steel balls in a cylindrical vessel containing a viscous liquid

Study of the free fall of steel balls in a cylindrical vessel filled with a viscous liquid is of interest in connection with a use of the SM for liquid viscosity measuring in this work. Inevitable errors associated both with the use of coaxial cylindrical vessels and freely falling balls in them arise at such viscosity measurements [20].

Study of the velocity dynamics of a steel ball during the transition from air to liquid is of independent interest.

In the experiments a steel ball with a diameter of $6 \mathrm{~mm}$, mass of $0.94 \mathrm{~g}$ and a steel ball with a diameter of $3 \mathrm{~mm}$ and a mass of $0.126 \mathrm{~g}$ were dropped into the liquid. 10W40 grade engine oil with a volume of $90 \mathrm{ml}$ and the aqueous solution of glycerol with glycerol concentration of $85 \%$ were used as a liquid. The height of the liquid column in the cylinder was $150 \mathrm{~mm}$. A special centering device in the form of a funnel was used to drop the ball; the funnel ended with a tube of a diameter slightly larger than the diameter of the ball and the axis of the tube and cylinder coincided. This device ensured the steel ball entering the oil along the axis of the cylinder at a specified drop height and eliminated the ball deviation from the cylinder axis in the oil. Such a ball motion in a viscous liquid corresponds to small Reynolds numbers $(\operatorname{Re}<<1000)[21]$ realized in experiments.

The time of the ball fall was determined within a height range set by marks on the cylindrical flask (1).

The velocity of the balls when entering the liquid was $1.2 \mathrm{~m} / \mathrm{s}$. The balls were dropped from a height of $73 \mathrm{~mm}$. The error in determining the velocity of the ball was $14-15 \%$.

Graphs of ball velocity variation over the entire height of the liquid in the vessel are presented in Fig. 5. The zero mark corresponds in the height of the column to the free boundary of the liquid. Curves obtained by cubic spline interpolation in MathCAD. 


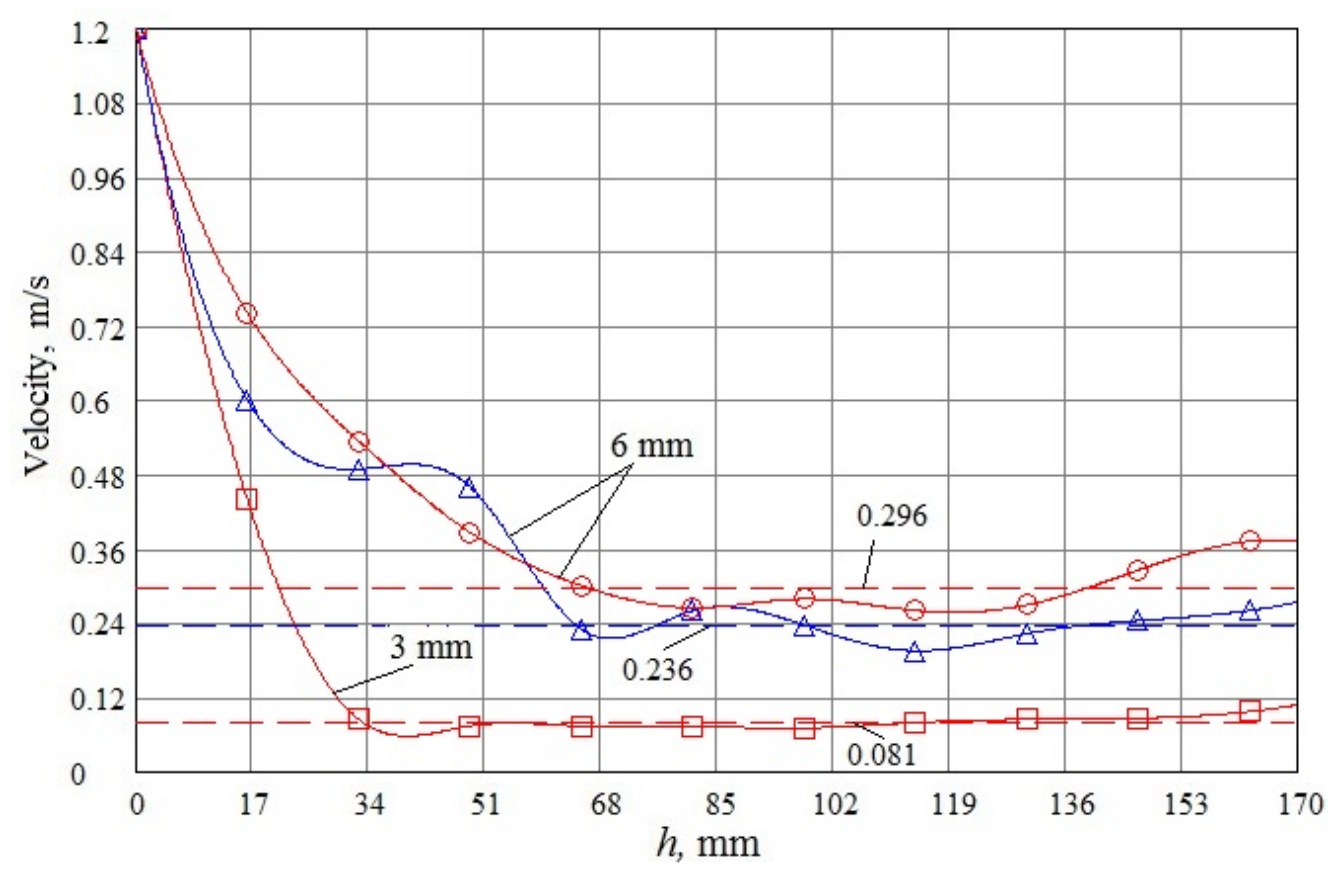

Figure 5. Dependence of the instantaneous velocities of steel balls on the height of a viscous liquid column $h$ in a cylindrical vessel: $\square, \circ$ - oil; $\Delta$ - glycerol

Figure 5 shows the occurrence of a transition mode of the ball motion velocity characterized by its damped oscillations. It follows from the figure that the confidence interval for measuring viscosity by the SM, where the ball moves uniformly, starts from a depth of $7.5 \mathrm{~cm}$. The average values of the velocity in this part of the trajectory are shown with a dotted line.

It should be noted that when considering the coincidence of the speed of motion of balls with diameters of $3 \mathrm{~mm}$ and $6 \mathrm{~mm}$ in oil at a finite interval of motion, it is necessary to take into account the measurement errors. In addition, the small, and not 4-times, according to the MS, the difference between these speeds is due to the screening of the cylinder wall [7].

It should be noted that the velocities of motion of balls with diameters of $3 \mathrm{~mm}$ and $6 \mathrm{~mm}$ in oil in the final interval of motion differ by approximately 3.75 times. A small deviation from the ratio of these velocities 4 - fold, which corresponds to the MS, due to measurement error, and shielding walls of the cylinder [7].

Based on the obtained result all subsequent measurements were carried out within the interval of uniform motion of steel balls.

\section{The viscosity of a liquid located in a rotating cylindrical vessel}

The experiments to study the viscosity of a liquid in a rotating cylindrical vessel were carried out using the SM [20]. The movement parameters of steel balls were analyzed at an interval of their uniform motion; they were determined experimentally in a series of preliminary experiments to study their free fall in a cylindrical vessel containing a viscous liquid. In the experiments, as noted above, the trajectory of the balls did not deviate from the axis of the cylinder. Besides, the vessel rotation did not lead to the ball rotation.

The viscosity coefficient of a rotating cylinder containing a liquid was determined by comparing the time of falling of a ball in a motionless liquid $t_{0}$ with the time of its falling $t_{\Omega}$ in a rotating in cylinder liquid. The relationship of these times obeys the ratio:

$$
t_{\Omega}=t_{0} \frac{\mu_{\Omega}}{\mu_{0}}
$$

were, $\mu_{\Omega}$ and $\mu_{0}$ - dynamic viscosity of a liquid with and without rotation, respectively.

Thus, knowing the ratio of the ball falling time in a rotating liquid to its falling time in a motionless liquid, the dynamic viscosity of a rotating liquid can be determined.

The experiments to determine the viscosity coefficient of a rotating liquid included a series of four measurements of the time of the ball falling in the liquid.

In the first series of experiments a steel ball with a diameter of $6 \mathrm{~mm}$ and a mass of 0.94 fell into the liquid. 10W40 grade engine oil of a volume of $90 \mathrm{ml}$ and of the oil column height in the cylinder of $150 \mathrm{~mm}$ was used as a liquid. The ball was dropped by hand at a certain height above the oil level. The time of its falling was recorded within a height range set by marks on the cylindrical flask (1). 
In the second series of experiments a steel ball with a diameter of $3 \mathrm{~mm}$ and a mass of $0.126 \mathrm{~g}$ was used. The other parameters of this series of experiments were the same as in the first series of experiments.

In the third series of experiments a special centering device was used, the purpose of which was described above. The other parameters of the third series of experiments were the same as in the second series.

In the fourth series of experiments the engine oil of 10W40 grade was replaced with a glycerol-water solution of $85 \%$ glycerol concentration. The other parameters of this series of experiments were the same as in the third series.

In the experiments a glass cylindrical flask with a diameter of $28 \mathrm{~mm}$ rotated with an angular rate, the value of which was set using the driver and varied within the range from 0 to $40 \mathrm{rpm}$. The steel ball was dropped from a certain height above the oil level. The time of its falling was within an interval of $150 \mathrm{~mm}$ in height, which was set by marks on a cylindrical flask (1). Then the obtained video sequences were processed using a computer. The time of ball motion in the liquid was determined by frame-by-frame analysis of the recorded video sequence at duration of one frame $\Delta \mathrm{t}=0.04 \mathrm{~s}$.

The results of measuring the dependence of the falling time of steel balls of different diameters on the rotation rate of a cylindrical vessel containing a viscous liquid are summarized in Table.

The dependence of the relative fall time $t_{\Omega} / t_{0}$ of steel balls of different diameters on the rotation rate of a cylindrical vessel containing a viscous liquid

\begin{tabular}{|c|c|c|c|c|}
\hline \multirow{4}{*}{$\begin{array}{l}\text { Rotation frequency } \Omega, \\
\qquad(\mathrm{rpm})\end{array}$} & \multicolumn{4}{|c|}{ Steel ball diameter $D,(\mathrm{~cm})$. } \\
\hline & \multicolumn{3}{|c|}{ Engine oil 10W40 } & \multirow{2}{*}{$\begin{array}{c}\begin{array}{l}\text { Glycerol }+ \text { water } \\
(85 \% \text { of glycerol })\end{array} \\
4 \text { series }\end{array}$} \\
\hline & 1 series & 2 series & 3 series & \\
\hline & $D=0.6^{\text {without c.d.) }}$ & $D=0.3^{\text {without c.d.) }}$ & $D=0.3^{\text {with c.d.) }}$ & $D=0.3^{\text {with c.d.) }}$ \\
\hline 0 & 1 & 1 & 1 & 1 \\
\hline 5 & - & - & 1.329 & 0.862 \\
\hline 10 & 0.94 & 0.987 & 1.191 & 0.936 \\
\hline 12.5 & - & - & 0.959 & - \\
\hline 15 & 0.978 & 0.941 & 0.844 & 0.894 \\
\hline 17.5 & - & - & 0.967 & - \\
\hline 20 & 0.778 & 0.955 & 0.946 & 0.83 \\
\hline 22.5 & - & - & 1.161 & - \\
\hline 25 & 0.933 & 0.926 & 1.028 & 0.787 \\
\hline 27.5 & - & - & 0.929 & - \\
\hline 30 & 0.784 & 0.892 & 0.958 & 0.915 \\
\hline 32.5 & - & - & 0.696 & - \\
\hline 35 & - & 0.918 & 0.92 & - \\
\hline 37.5 & - & - & 0.997 & - \\
\hline 40 & 0.814 & 0.929 & 0.929 & - \\
\hline
\end{tabular}

without c.d.) - without centering device with c.d.) - with centering device

Discussion of the results of a study of the viscosity of a liquid located in a rotating cylindrical vessel

The results of measurements of the average time of balls falling into a viscous liquid depending on the rotation frequency of a cylindrical vessel are presented in Fig. 6.

As can be seen from Fig. 6, in the first series of experiments (marker $\square$ ) the relative time of falling balls decreases on average with increasing the rotation frequency of a viscous liquid in a vessel. In this context the periodic minima are observed at multiple frequencies of 10,20, and $30 \mathrm{rpm}$.

In the second series of experiments (marker $\Delta$ ) poor oscillations of the time of balls motion are also observed at a general decrease of their falling time with increasing the vessel rotation frequency. The minima of the ball falling time at multiple frequencies of 15 and $30 \mathrm{rpm}$ repeat the dynamics of previous experiments, but at high rotation frequencies.

In the 3 rd and 4th series of experiments the resonance nature of the dependence of the balls falling time on the vessel rotation frequency is also observed.

In the 3rd series (marker $\circ$ ) the minima of the ball falling time are near the values of 15 and $32 \mathrm{rpm}$.

In series 4 (marker $\diamond)$ such a resonant behavior of the ball falling time depending on the rotation frequency is poorly resolved, but can be detected. 


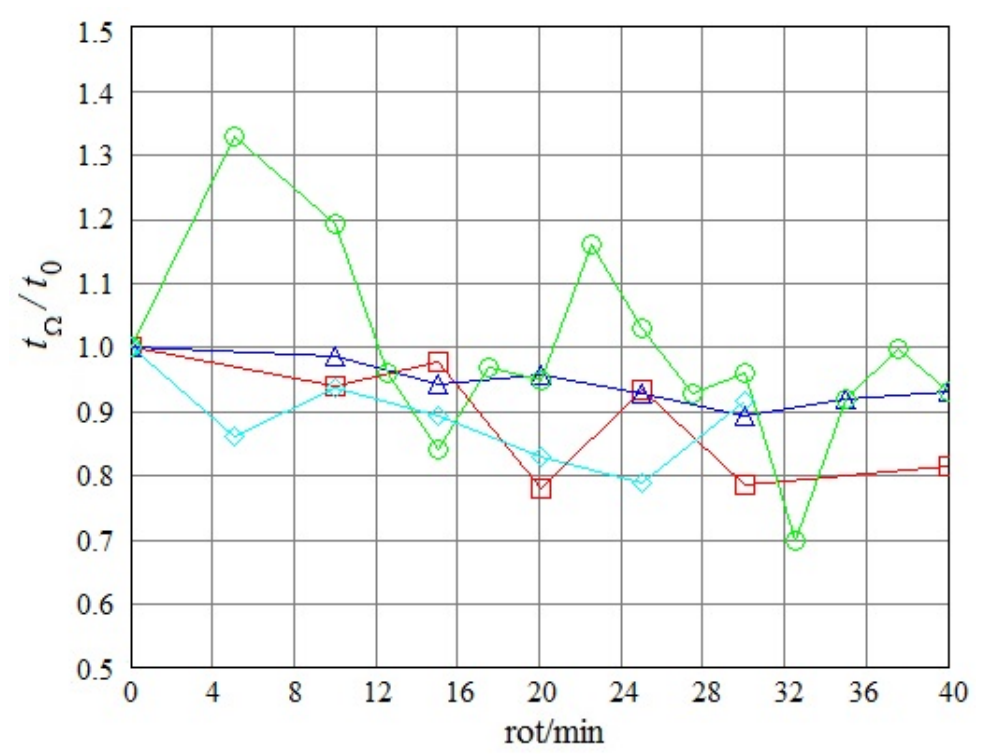

Figure 6. Dependence of the average relative time $t_{\Omega} / t_{0}$ of balls falling upon the rotation frequency of a cylindrical vessel containing a viscous liquid: $\square-1$ series; $\Delta-2$ series; $\circ-3$ series; $\diamond-4$ series.

The general behavior in all series of experiments is decreasing the time of balls fall with increasing the vessel rotation frequency and the existence of a resonant dependence of the dynamic viscosity coefficient on the vessel rotation rate.

One of the possible explanations for the observed oscillations of the balls moving time is the occurrence of natural frequencies of oscillations in the liquid [12] or the occurrence of spatially periodic structures in the ball-oil-flask system [22].

An experimental study of vortex formation in a liquid, located in a rotating cylindrical vessel

In the experiments 10W40 grade oil painted with a small amount of bronze powder was fed from the top through a centering device until a thin surface layer of a colored liquid with a thickness of 3-4 mm was formed. A cylindrical vessel with a viscous liquid of a diameter of $28 \mathrm{~mm}$ and a height of $150 \mathrm{~mm}$ rotated with different angular rates from 5 to $40 \mathrm{rpm}$.

The following was found in the experiments.

In contrast to raising the black ink vortexes from the bottom of the vessel described in [10], in the experiments of the authors we studied the lowering of colored 10W40 engine oil from a thin surface layer.

The lowering began after 15 to 20 minutes of the vessel rotation. The colored liquid drifted in the vertical direction to the bottom of the vessel in the form of several separate vortexes of different lengths at low velocities compared with the liquid rotation rate. The generated vortexes had the form of threadlike curved spirals of colored oil parallel to the axis of the cylinder.

The type of vortices at the initial stage of their formation is shown in Fig. 7.

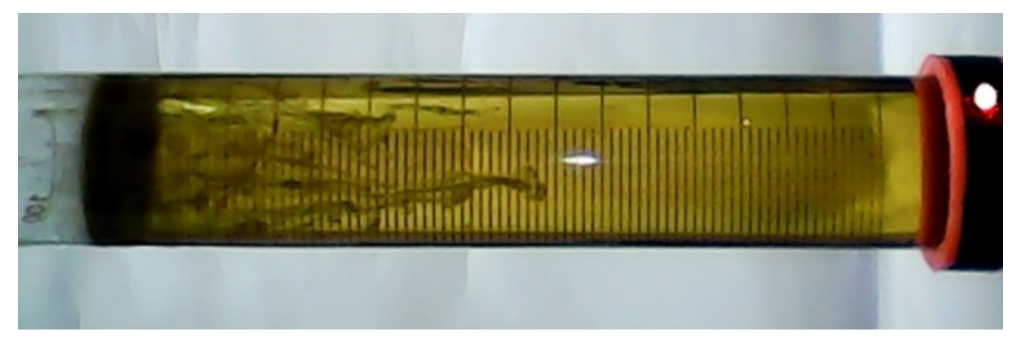

Figure 7. Generation of vortices of colored oil in a rotating cylindrical vessel. The photo is reduced to horizontal view.

Analysis of the recorded video sequence using a digital microscope made it possible to determine the average velocities of the vertical drift of the powder particles. When the viscous liquid rotated at a rate of $15 \mathrm{rpm}$, the vertical drift velocity of the particles was $0.47 \mathrm{~mm} / \mathrm{s}, 30 \mathrm{rpm}-0.50 \mathrm{~mm} / \mathrm{s}, 40 \mathrm{rpm}-0.63 \mathrm{~mm} / \mathrm{s}$.

Analyzing the experimental results obtained in the work the following facts were found:

- several threadlike spiral flows of colored liquid parallel to the cylinder axis are formed during rotation;

- with increasing the liquid rotation rate, the downward drift velocity of the colored liquid also increases; 
- the downward drift velocities of the colored threadlike flows in the rotating liquid increased from the periphery towards the center of the vessel.

Thus, the spatial structuration of flows corresponding to vortex formation in a viscous liquid was demonstrated experimentally in this section.

\section{CONCLUSIONS}

The results of the experimental study of free fall of steel balls in a viscous liquid, as well as the viscosity and the vortex formation in a liquid located in a rotating cylindrical vessel were presented in the paper.

The occurrence of a transitional mode of a ball velocity characterized by damped oscillations of the ball velocity after passing it through the upper boundary of the liquid was demonstrated. The confidence interval in the liquid column height was determined, where the SM for measuring the liquid viscosity can be used.

It has been experimentally shown that a general regularity of the process is a decrease in the time of balls falling with increasing the vessel rotation frequency.

The occurrence of the resonant dependence of the ball falling time and therefore the coefficient of the dynamic viscosity on the vessel rotation rate was also demonstrated. This dependence is expressed by periodic in rotation frequency variation of the dynamic viscosity coefficient against its general decreasing background.

Analyzing the experimental results obtained in the paper it has been found that several threadlike spiral flows of the colored liquid parallel to the axis of the cylinder are formed at the cylindrical vessel rotation. The velocity of the downward drift of the colored liquid increases with increasing its rotation rate and it increases from the periphery to the center of the vessel.

\section{ORCID IDs}

(DOksana L. Andrieieva, https://orcid.org/0000-0001-9757-8519; (DLeonid A. Bulavin, https://orcid.org/0000-0002-8063-6441; (DIgor N. Kudriavtsev, https://orcid.org/0000-0001-6677-9289; (DR.S. Sokolenko, https://orcid.org/0000-0001-6895-2006;

(D)Victor I. Tkachenko, https://orcid.org/0000-0002-1108-5842

\section{REFERENCES}

[1] L.D. Landau, and E.M. Lifshits, Теоретическая физика. Гидродинамика, T.6, [Theoretical physics. Hydrodynamics, Vol.6,] (Nauka, Moscow, 1986), pp. 736. (in Russian)

[2] E.G. Richardson, Proc. Phys. Soc. 61(4), 352-367 (1948), https://doi.org/10.1088/0959-5309/61/4/308.

[3] M. Stephen, and Jr. Laverty, M.Sc. thesis, Massachusetts Institute of Technology, 2004, http://web.mit.edu/mhl/www/Impact\%20Lab\%20Page/Whole\%20Thesis.pdf

[4] A.B. Lotov, Uchenyie zapiski TsAGI, 2(4), 22-30 (1971). (in Russian).

[5] I. Mirzaii, and M. Passandideh-Fard, in: 19th Annual Conference on Mechanical Engineering-ISME-2011, (The University of Birjand, Iran, 2011), pp. 1-4. https://www.researchgate.net/publication/307510320_The_Impact_of_a_Solid_Object_on_to_a_Liquid_Surface

[6] H. Wagner, Math. Mech. 12, 193-215 (1932), http://dx.doi.org/10.1002/zamm.19320120 $\overline{2} 402$.

[7] V. Fidleris, and R.L. Whitmore, Br. J. Appl. Phys. 12, 490-494 (1961), https://doi.org/10.1088/0508-3443/12/9/311.

[8] P.P. Brown, and D.F. Lawler, Journal of Environmental Engineering, 129(3), 222-231 (2003), https://doi.org/10.1061/(ASCE)0733-9372(2003)129:3(222).

[9] Rayleigh Lord, Proc. Roy. Soc. London, Series A, 93(648), pp. 148-154. Scientific papers, 6, 447-453, (Cambridge University Press, 1917), pp. 254, https://www.jstor.org/stable/93794.

[10] S. Chandrasekhar, Hydrodynamic and hydromagnetic stability, (Oxford University Press, 1970), pp.657. https://www.cambridge.org/core/journals/journal-of-fluid-mechanics/article/universal-stability-of-hydromagneticflows/826D62658D200A2DCE37F6006EE4390A

[11] Y. Nakagawa, and P. Frenzen, Tellus. 7(1), 1-21 (1955), https://doi.org/10.3402/tellusa.v7i1.8773.

[12] H.P. Grinspen, Теория вращающихся жидкостей [Rotating fluid theory], (Gidrometeoizdat, Leningrad, 1975), pp. 321, https://www.twirpx.com/file/243427/. (in Russian)

[13] H. Bernard, Revue generale des Sciences, Pures et Appliques, 11, 1261-1271 and 1309-1328 (1900).

[14] O.L. Patochkina, B.V. Borts, and V.I. Tkachenko, East Eur. J. Phys. 2(1), 23-31 (2015). https://periodicals.karazin.ua/eejp/article/view/2810

[15] R. Skorer, Аэрогидродинамика окружающей среды [Aero-hydrodynamics of the environment], (Mir, Moscow, 1980), pp. 550. (in Russian)

[16] M. Van-Dajk, Альбом течений жидкости и газа [Album of liquid and gas flows], (Mir, Moscow, 1986), pp. 184. (in Russian)

[17] A.S. Monin, and G.M. Zhiharev, UFN, 160(5), 1-47 (1990), https://doi.org/10.3367/UFNr.0160.199005a.0001. (in Russian)

[18] A.V. Tur, and V.V. Janovskij, Гидродинамические вихревые структуры [Hydrodynamic vortex structures], (Har'kov, NTK "Institut Monokristallov", 2012), pp. 294. (in Russian)

[19] O.L Andreeva, L.A. Bulavin, I.M. Kudrjavcev, R.S. Sokolenko, and V.I. Tkachenko, in: International scientific and technical conference "Physical And Technical Problems Of Energy And Their Solutions 2019", (KhNU, Kharkiv, 2019), pp. 18-19, http://physics-energy.karazin.ua/resources/17c5203634424b2292944e8da8f6c686.pdf. (in Russian)

[20] F. Sherman, editor, Эмульсии [Emulsions], (Himija, Leningrad, 1972), pp. 448, https://www.studmed.ru/sherman-f-redemulsii_1553621cafe.html. (in Russian)

[21] M.V. Krautsou, A.M. Krautsou, Izvestiâ vysših učebnyh zavedenij i ènergetičeskih ob"edinennij SNG. Ènergetika, 2, 80-87 (2011), https://energy.bntu.by/jour/article/download/301/296 (in Russian)

[22] E.L. Koschmieder, Benard Cell and Taylor Vortices, (Cambridge University Press, 1993), pp. 337. 


\section{В’ЯЗКІСТЬ І ВИХРОУТВОРЕННЯ В РІДИНІ, ЩО ОБЕРТАЄТЬСЯ В ЦИЛІНДРИЧНІЙ СМНОСТІ \\ О.Л. Андрсєва ${ }^{\text {a,b }}$, Л. А. Булавін ${ }^{c}$, І. М. Кудрявцев ${ }^{\text {b }}$, Р.С. Соколенко ${ }^{\text {a }}$, В.І. Ткаченко ${ }^{\text {a,b }}$ \\ ${ }^{a}$ ННЦ "Харківський фізико-технічний інститут", Харків \\ ${ }^{b}$ Харківський національний університет імені В.Н. Каразіна, Харків \\ 'Київський національний університет імені Тараса Шевченка, Київ}

Експериментально досліджено вільне падіння сталевих кульок різних діаметрів у в'язких рідинах, поміщених в циліндричну посудину, що покоїться або обертається 3 постійною швидкістю, а також вихроутворення рідини, що обертається в циліндричній посудині. Для дослідження цих питань розроблений експериментальний стенд, що складається з циліндричної скляної посудини, встановленої на осі валу електродвигуна 3 регульованими оборотами, контрольно-вимірювального обладнання в складі цифрового лазерного тахометра, цифрового USB-мікроскопа і ноутбука, для візуалізації досліджуваних процесів. Отримано експериментальні залежності миттєвої швидкості кульок від пройденої ними відстані. Показано наявність перехідного режиму зміни швидкості кульки при його вході в рідину. Перехідний режим характеризується загасаючою, періодичною змінною від відстані миттєвою швидкістю. Встановлено, що на певній пройденій кулькою відстані, перехідний режим переходить в стаціонарний, коли кулька рухається з постійною швидкістю. У стаціонарному режимі методом Стокса досліджена залежність в'язкості рідини від частоти обертання посудини. Показано, що загальною закономірністю таких процесів є зменшення часу падіння кульок, а, отже, коефіцієнту динамічної в'язкості рідини, з ростом частоти обертання посудини. Експериментально виявлено періодична зміна коефіцієнту динамічної в'язкості від частоти обертання посудини. Експериментально встановлено, що при обертанні циліндричної посудини утворюється кілька паралельних осі циліндра ниткоподібних спіральних потоків пофарбованої рідини. При цьому швидкість низхідного дрейфу пофарбованої рідини зростає зі збільшенням швидкості іiї обертання, а також вона збільшується від периферії до центру судини.

КЛЮЧОВІ СЛОВА: рідина, циліндрична ємність, постійна швидкість, в'язкість, метод Стокса, обертання, динамічна в'язкість, вихор

ВЯЗКОСТЬ И ВИХРЕОБРАЗОВАНИЕ В ЖИДКОСТИ, ВРАЩАЮЩЕЙСЯ В ЦИЛИНДРИЧЕСКОМ СОСУДЕ

О.Л. Андреева ${ }^{\mathrm{a}, \mathrm{b}}$, Л.А. Булавин ${ }^{\mathrm{c}}$, И.Н. Кудрявцев ${ }^{\mathrm{b}}$, Р.С. Соколенко ${ }^{\mathrm{a}}$ В.И. Ткаченко ${ }^{\mathrm{a}, \mathrm{b}}$

${ }^{a} Н Н Ц$ "Харьковский физико - технический институт", Харьков

${ }^{b}$ Харьковский начиональный университет имени В.Н. Каразина, Харьков

${ }^{c}$ Киевский национальный университет имени Тараса Шевченко, Киев

Экспериментально исследовано свободное падения стальных шариков разных диаметров в вязких жидкостях, помещенных в покоящийся или вращающийся с постоянной скоростью цилиндрический сосуд, а также вихреобразование во вращающейся в цилиндрическом сосуде жидкости. Для исследования этих вопросов разработан экспериментальный стенд, состоящий из цилиндрического стеклянного сосуда, установленного на оси вала электромотора с регулируемыми оборотами, контрольно-измерительного оборудования в составе цифрового лазерного тахометра, цифрового USBмикроскопа и ноутбука, для визуализации исследуемых процессов. Получены экспериментальные зависимости мгновенной скорости шариков от пройденного ими расстояния. Показано наличие переходного режима изменения скорости шарика при его входе в жидкость. Переходной режим характеризуется затухающим, периодическим изменением мгновенной скорости от расстояния. Установлено, что на определенном, пройденном шариком расстоянии, переходной режим переходит в стационарный, когда шарик движется с постоянной скоростью. В стационарном режиме методом Стокса исследована зависимость вязкости жидкости от частоты вращения сосуда. Показано, что общей закономерностью таких процессов является уменьшение времени падения шариков, а, следовательно, коэффициента динамической вязкости жидкости, с ростом частоты вращения сосуда. Экспериментально обнаружено периодическое изменение коэффициента динамической вязкости от частоты вращения сосуда. Экспериментально установлено, что при вращении цилиндрического сосуда образуется несколько параллельных оси цилиндра нитевидных спиральных потоков окрашенной жидкости. При этом скорость нисходящего дрейфа окрашенной жидкости возрастает с увеличением скорости ее вращения, а также она увеличивались от периферии к центру сосуда.

КЛЮЧЕВЫЕ СЛОВА: жидкость, цилиндрический сосуд, постоянная скорость, вязкость, метод Стокса, вращение, динамическая вязкость, вихри 